Jurnal Teknologi, 37(F) Dis. 2002: 55-64

(C) Universiti Teknologi Malaysia

\title{
THE ROLE OF SOCIO-ECONOMIC AND CULTURAL FACTORS IN MUNICIPAL SOLID WASTE GENERATION: A CASE STUDY IN TAMAN PERLING, JOHOR BAHRU
}

\author{
MOHD. BADRUDDIN MOHD.YUSOF ${ }^{1}$, FADIL OTHMAN ${ }^{2}$, NORMALA \\ HASHIM \& NUR CAHAYA ALI
}

\begin{abstract}
The absence of a comprehensive database on solid waste generation and composition appears to be the major drawback to the development of an integrated waste management system in Malaysia. While many studies have been conducted on related fields, such as Abd. Karim et al. (1996), Sabarinah (1997), and Salim et al. (1994), there is still a lack of clear model or approach in determining attributes influencing the amount of wastes generated by our community. A study conducted in Taman Perling, Johor Bahru has shown that such as attributes as income, education, and other socioeconomic factors barely affect the amount of waste generated. It seems that only family size and lifestyle factors, particularly the eating habits of residents, contribute significantly to variations in the generation of residential waste in the study area. While the amount increases with the size of family, it decreases as the respondents dine out more often. This study suggests new insights concerning the role of social factors and lifestyle in affecting the generation of household waste.
\end{abstract}

Key words: Domestic waste generation, socio-economic factors, family size, lifestyle, eating habits

\begin{abstract}
Abstrak. Satu daripada masalah utama dalam pembangunan sistem pengurusan sisa pepejal bersepadu di Malaysia ialah kekurangan data menyeluruh tentang penjanaan dan komposisi sisa. Perkara ini perlu diatasi demi memudahkan perancangan pengurusan pada masa akan datang. Walaupun terdapat banyak kajian tentang sisa pepejal, antaranya ialah Abd. Karim et al. (1996), Sabarinah (1997), dan Salim et al. (1994), tetapi model dan pendekatan yang lebih jelas masih diperlukan bagi menentukan faktor yang mempengaruhi penjanaan sisa pepejal oleh sesebuah komuniti di Malaysia. Kajian yang telah dijalankan di Taman Perling, Johor Bahru mendapati bahawa faktor pendapatan, pendidikan, lain-lain faktor kemasyarakatan kurang mempengaruhi jumlah penjanaan sisa pepejal domestik. Hanya faktor saiz isi rumah dan cara hidup menunjukkan korelasi terhadap jumlah sisa yang dijana. Jumlah sisa berkorelasi secara positif dengan saiz isi rumah, tetapi berkorelasi secara negatif terhadap kekerapan makan di luar rumah. Ini bermakna, pada lazimnya, keluarga besar menjana jumlah sisa yang lebih banyak daripada keluarga yang bersaiz kecil. Begitu juga dengan mereka yang jarang mengunjungi restoran atau gerai makan didapati menghasilkan sisa lebih berbanding keluarga yang kerap makan di luar rumah. Hasil kajian memberi perspektif yang baru terhadap teori penjanaan sisa yang selama ini kerap mengaitkan aspek pendapatan dan faktor sosioekonomi dengan jumlah sisa domestik. Penemuan ini juga mengajar kita supaya lebih prihatin terhadap faktor sosial dan gaya hidup yang mempengaruhi tren penjanaan sisa, seterusnya dalam usaha menangani masalah pengurusan sisa pepejal domestik pada masa akan datang.
\end{abstract}

Kata kunci: sisa domestik, faktor sosioekonomi, saiz keluarga, cara hidup dan tabiat pemakanan

\footnotetext{
${ }^{1}$ Faculty of Civil Engineering, Universiti Teknologi Malaysia, Skudai, Johor Bahru. E-mail: badrudin@fka.utm.my

${ }^{2}$ Assoc. Professor at Faculty of Civil Engineering, Universiti Teknologi Malaysia, Skudai, Johor Bahru.
} 


\subsection{INTRODUCTION}

The continuous growth of economic and population in Malaysia has brought a new challenge to the local governments especially in dealing with the issue of municipal solid waste (MSW) disposal, particularly domestic household wastes. An average individual Malaysian is now producing $0.95 \mathrm{~kg}$ of wastes per day. The capital city of Kuala Lumpur is generating daily wastes of $2,500 \mathrm{~kg}$, while Johor Bahru has to put up with $1,300 \mathrm{~kg}$ (The Southern Waste Management, 2001). The latter represents an amount that capables of filling up a hockey field or all three lanes of the Tambak Johor with a depth of 1 foot within three days. With the number increasing at 2-3 percent, imagine what the current population of 23 million (2000 Census) can do to the already depleting landfill sites around the country! Malaysia has to step up its waste reduction actions in dealing with the current problem, where 80 percent of our 230 landfills in Malaysia are currently utilized, or face with even greater environmental challenges in the years ahead.

Many studies have associated various factors affecting the generation of residential wastes including family size, social status and wealth, residential location, and community status - all of which were of social attributes (A.Karim, 1996), Kaur (1995), Salim et al. (1994)). Sabarinah (1997) found that the income and lifestyles contributed to the generation of waste among Johoreans, particularly in terms of the use of specific products such as disposable diapers. A. Karim (1996), for instance, had developed a formula linking various factors affecting the total residential waste in Taman Ungku Tun Aminah, Johor Bahru. The formula is as follows:

$$
G=a P+B R+r I+u C+t
$$

where

$$
\begin{array}{ll}
G & =\text { total daily waste from a family }(\mathrm{kg} / \text { person/day }) \\
P & =\text { total family members } \\
R & =\text { number of rooms } \\
I & =\text { income } \\
C & =\text { religious/cultural background } \\
a, B, r, \text { and } u & =\text { constant } \\
t & =\text { constant at Y-axis }
\end{array}
$$

It is therefore timely that social aspects of the waste management issue be emphasized rather than concentrating mainly on the technical side of the matter, if any major improvements were to be made in the near future.

\subsection{OBJECTIVES}

The main objective of the study is to collect data on domestic waste generated by residents living in Taman Perling, situated within the jurisdiction of the Majlis Perbandaran Johor Bahru Tengah (MPJBT). Other objectives, include: 
(i) to analyze the rate of waste generation in the study area,

(ii) to relate the waste data to the socio-economic data and life styles of the residents, and

(iii) to study the eating habits of residents and their role in affecting the waste generation.

\subsection{Scope}

This study covers the residential area of Taman Perling, located $12 \mathrm{~km}$ from the central city of Johor Bahru. In order to evaluate the gathered data effectively and maintain the scope within a stipulated time and financial limit, the study emphasized on the domestic waste only without taking into account other types of institutional, yard or industrial wastes. Waste samples were weighed individually on site from the individual homes before they were disposed at dumpsites. The residents interviewed were randomly selected and lived in various types of housing units including terraces, flats, and village or 'kampung' houses. A sample size of 100 respondents appeared to be reasonable enough to give a 90 percent confidence level Census (Yamane, 1973) in the study area with a population of 34,000 (2000 Census).

\subsection{METHODOLOGY}

Malaysia, like many other developing or newly developed countries, is now facing the issue of difficulty in finding suitable landfill sites, outdated or old equipments, limited public support, absence of control of packages used, as well as illegal squatters (The Southern Waste Management, 1998) - most of which are waste-related problems. It is therefore reasonable to assume that reduction of our wastes would definitely curb, if not solve, the whole problems stated.

Most environmentalists would agree that in order to comprehensively deal with the whole issue, it is a prerequisite to understand the nature of our solid wastes in terms of their composition and volumes generated (Park, 1998). Foreign experts have pointed out that the difficulty in finding solutions to the problem with the current situations in Malaysia is due to a lack of background data on its wastes (Nakamura, 1989). The nation definitely needs an information system on waste generation and composition if an integrated waste management system was to be implemented. It is therefore important that researchers start to compile data on such matters if a comprehensive master plan of solid waste management in the country was to be successfully developed and followed.

\subsection{List of Questionnaires}

Questionnaires used in the study to gather information ranging from the respondents' personal and socio-economic background to total waste generated as well as their 
eating and cooking habits. Respondents were given a list of questionnaires ranging from personal and social background information to income level, educational achievement, characteristics and types of their residential units, as well as their lifestyle, particularly their weekly home-cooking and 'eating-out' activities. Objective answers were given and a 5 -scale Likert system was used (in certain questions requiring opinions; for instance, 5 -strongly agree, 4-agree, 3- neutral, 2- disagree, and 1-strongly disagree) to ease the process of answering and data manipulation.

\subsection{Background Analysis of Study Area}

Data on population of Taman Perling, geographical information, types of housing units, total wastes generated, and parties involved in the waste management or recycling programs were required in the study. The information was gathered from local authorities (Majlis Perbandaran Johor Bahru Tengah (MPJBT), the Southern Waste Management (SWM), and the Department of Statistics.

\subsection{Sample Size}

The study used a sample size of 100 respondents. The respondents interviewed were chosen randomly from various housing units including terraces, flats, and village or 'kampung' houses, while their wastes were weighed on site. A weighing machine of $100 \mathrm{~kg}$ capacity was used to weigh the waste samples. Only dry wastes were weighed while fruit skins were omitted, in order to avoid variations due to high moisture contents during rain and fruit seasons. The respondents came from various housing establishments: low, medium, as well as high-cost housing units, to provide diversification of opinions and avoid possibilities of biased responses.

\subsection{Analysis of Data}

Analyses cover both descriptive as well as inferential statistics, including bivariate and linear regression analysis. While the former was used to describe background information of the sample population, the latter analysed the relationships between the respondents' behaviour and the amount of wastes generated. The Statistical Packages for Social Sciences (SPSS) program was used in the analysis.

Attributes in the study include gender, age, race, education, marital status, religious affiliation, income, house category, ownership status, type of housing unit, family size, as well as eating habits, home-cooking activities, and daily waste weights. Hypothesis of the study stated that the amount of wastes were directly linked to income, family size, and home-cooking activities. 


\subsection{ANALYSIS OF RESULT}

\subsection{Demographics}

Based on the sample size of 100, 49 respondents were male, while the rest female. Majority of them were Malay (80\%) and in the age category of 26 to 35 years old. Other races were reported to be less co-operative when asked for feedback. Most of the respondents obtained some form of formal, high school education, while majority belonged to RM500 and RM1,500 income group (Table 1).

Table 1 Respondents' background data

\begin{tabular}{|c|c|c|c|c|c|}
\hline \multirow[t]{2}{*}{ Gender } & \multirow{2}{*}{$\frac{\text { Male }}{49}$} & \multirow{2}{*}{$\begin{array}{l}\text { Female } \\
51\end{array}$} & & & \\
\hline & & & & & \\
\hline \multirow[t]{2}{*}{ Race } & Malay & Chinese & Indian & $\begin{array}{l}\text { Mixed } \\
\text { Parentage }\end{array}$ & \\
\hline & 81 & 12 & 4 & 7 & \\
\hline \multirow[t]{2}{*}{ Religion } & Islam & Christian & Buddhism & Hinduism & \\
\hline & 84 & 3 & 9 & 4 & \\
\hline \multirow[t]{2}{*}{ Age (Years) } & $15-20$ & $21-25$ & $26-35$ & $36-55$ & 55 and above \\
\hline & 7 & 18 & 30 & 39 & 6 \\
\hline \multirow[t]{2}{*}{ Education } & $\begin{array}{l}\text { High } \\
\text { School }\end{array}$ & Diploma & $\begin{array}{l}\text { College } \\
\text { Degree }\end{array}$ & $\begin{array}{l}\text { Post- } \\
\text { graduate }\end{array}$ & Others \\
\hline & 53 & 13 & 16 & 3 & 15 \\
\hline \multirow{3}{*}{$\begin{array}{l}\text { Income } \\
(\mathbf{R M})\end{array}$} & $0-300$ & $301-500$ & $501-1500$ & $1501-2000$ & 2000 and above \\
\hline & 6 & 9 & 51 & 18 & 16 \\
\hline & Professional & $\begin{array}{l}\text { Teachers/ } \\
\text { Academician }\end{array}$ & Businessmen & Government & Supervisors \\
\hline \multirow[t]{3}{*}{ Occupation } & 9 & 6 & 2 & 8 & 6 \\
\hline & Factory & $\begin{array}{l}\text { Self- } \\
\text { employed }\end{array}$ & Retired & Students & House-wives \\
\hline & 9 & 11 & 6 & 15 & 28 \\
\hline
\end{tabular}

\subsection{Housing Types}

In order to represent the overall community of the study area, wastes were collected from various housing units. The result is shown in Table 2. Majority of the respondents lived in terrace units (85), while others in flats (10), and 'kampung' houses (5). 
Table 2 Number of respondents according to residential types

\begin{tabular}{|l|c|}
\hline Housing Types & Respondents \\
\hline Terrace & 85 \\
Flat & 10 \\
Kampung & 5 \\
\hline Total & $\mathbf{1 0 0}$ \\
\hline
\end{tabular}

\subsection{Waste Weight, Socio-economic Background, Housing Types, and Lifestyles}

The average rate of waste generation of the study area stood at $1.16 \mathrm{~kg}$ per household per day (i.e. obtained by dividing the waste weight by the number of days collected). It is important not to compare the amount to the per capita generation, as the study did not cover yard wastes and bulky products, like furniture, used electrical goods etc. (also considered as a part of municipal solid waste (MSW)). The country's average per capita waste generation stands between 0.4 and $1.3 \mathrm{~kg} /$ day (The Southern Waste Management, 1998).

Various statistical analyses were conducted including bivariate as well as linear regression to determine associations between determining independent variables (such as socio-economic factors, lifestyle attributes, and housing characteristics) and dependent variable (such as the weight). The Pearson correlation coefficient values obtained would determine the attributes that significantly influenced the weight of household wastes.

A bivariate analysis was used to see any correlations between waste weight and other variables. The test of significance (at 95 percent confidence level) and Pearson's $r$ values of the analysis showed that only the frequency of dining out and home-cooking activity, as well as family size, have a direct effect on the daily waste weight, i.e. the $r$ values were $-0.333,0.280$, and 0.257 , all of which were significant at 0.01 or 99 percent, respectively with t-test values of less than 0.05 (Table 3 ).

The relationship between weight and family-size as well as eating habit are shown in Figures 1 and 2. The results showed that the weight increases correspondingly to the size of the family, but decreases as the families dine out more frequently.

From the stepwise, linear regression analysis was conducted. All insignificant determinant variables were omitted, leaving behind only two attributes; dining out and family-size, as shown in Table 4. As observed, the variable, 'home-cooking' was also omitted from the regression analysis, implying its insignificant role in the formula.

A formula can be developed linking the attributes to the household weight:

$$
W=1.120-0.125(\mathrm{DO})+0.191(\mathrm{FS})
$$


Table 3 Pearson's correlation coefficients (generation of waste by social attributes, housing characteristics, and lifestyle)

\begin{tabular}{|l|c|c|}
\hline Attributes & Waste weight \\
\hline (A) Social factors & $\begin{array}{c}\text { Pearson } \\
\text { correlation } \\
\text { coefficients }\end{array}$ & $\begin{array}{c}\text { Significant test } \\
\text { (2-tailed) }\end{array}$ \\
\hline (1) Sex & 0.045 & Not Significant \\
\hline (2) Age & 0.056 & Not Significant \\
\hline (3) Race & -0.110 & Not Significant \\
\hline (4) Education & -0.011 & Not Significant \\
\hline (5) Marital status & 0.072 & Not Significant \\
\hline (6) Religion & -0.052 & Not Significant \\
\hline (7) Income & -0.071 & Not Significant \\
\hline (B) Housing characteristics & & Not Significant \\
\hline (1) House category & 0.135 & Not Significant \\
\hline (2) Ownership status & -0.038 & Not Significant \\
\hline (3) Unit types & 0.047 & 0.010 \\
\hline (4) Family size & $0.257^{*}$ & 0.001 \\
\hline (C) Lifestyle & $-0.333^{*}$ & \\
\hline (1) Dining out & $0.280^{*}$ & \\
\hline (2) Home cooking & & \\
\hline
\end{tabular}

$\left({ }^{*}\right)$ Significant at 0.01 level

where,

$W \quad=$ Total daily residential waste $(\mathrm{kg} /$ household/day $)$

$\mathrm{DO}=$ Frequency of dining out

FS = Family size

$1.120=$ constant at $Y$-axis. 


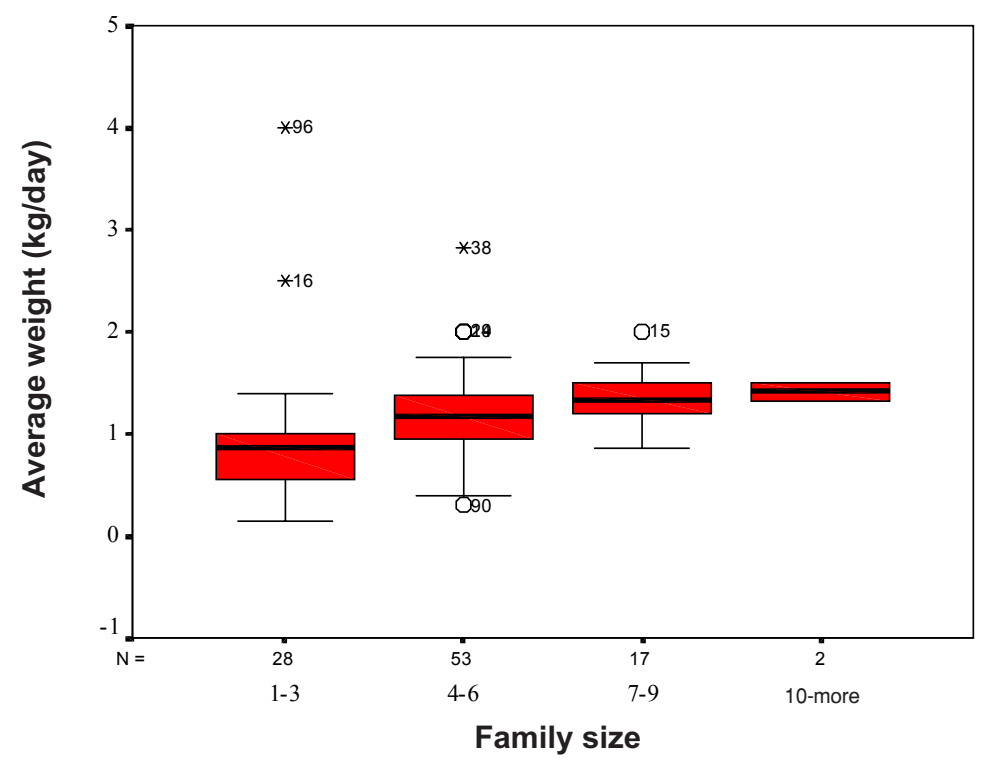

Figure 1 Average weight by family size

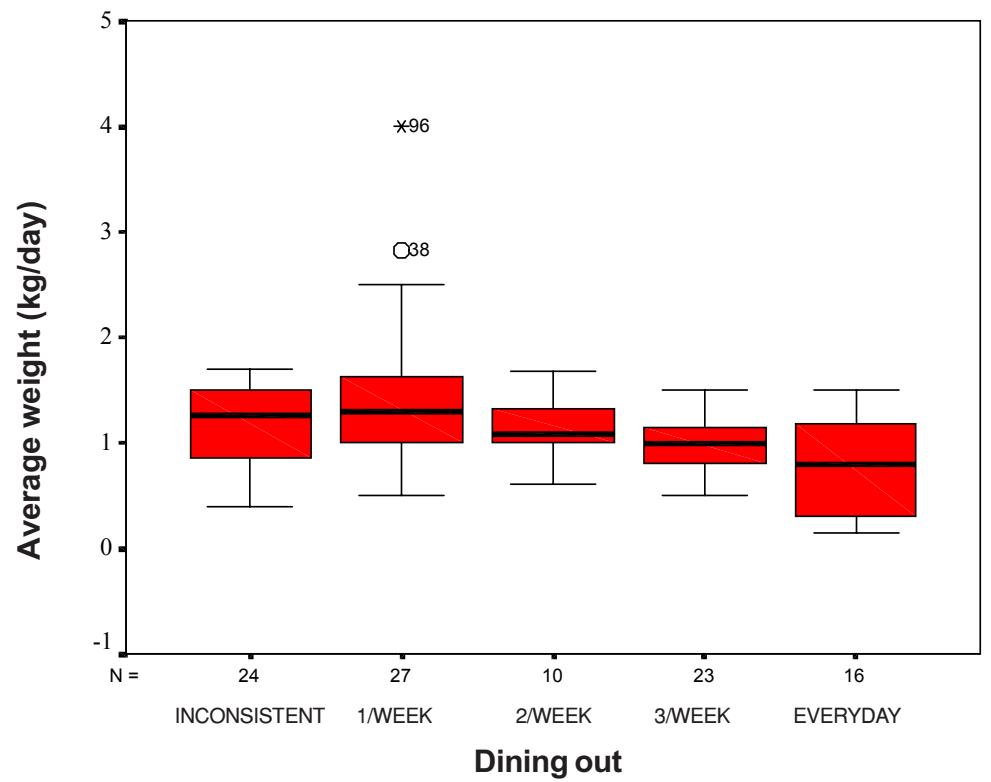

Figure 2 Average weight by dining activity

\subsection{CONCLUSION}

The analysis shows that despite many previous theories associating higher income and economic status with higher waste volume, these findings certainly do not apply in this particular study. The study partly agrees with Sabarinah (1997), however, as far 
Table 4 Linear regression (waste weight, family size and life style)

\begin{tabular}{|c|c|c|c|c|c|c|c|c|c|c|}
\hline & \multicolumn{2}{|c|}{$\begin{array}{l}\text { Unstandardized } \\
\text { coefficients }\end{array}$} & \multirow{2}{*}{$\begin{array}{c}\begin{array}{l}\text { Standardized } \\
\text { coefficients }\end{array} \\
\text { Beta }\end{array}$} & \multirow[t]{2}{*}{$\mathbf{t}$} & \multirow[t]{2}{*}{ Sig. } & \multicolumn{2}{|c|}{$\begin{array}{c}\text { 95\% Confidence } \\
\text { Interval for } \mathbf{B}\end{array}$} & \multicolumn{3}{|c|}{ Correlations } \\
\hline & $\mathbf{B}$ & Std. error & & & & $\begin{array}{l}\text { Lower } \\
\text { bound }\end{array}$ & $\begin{array}{l}\text { Upper } \\
\text { bound }\end{array}$ & $\begin{array}{l}\text { Zero- } \\
\text { order }\end{array}$ & Partial & Part \\
\hline (Constant) & 1.120 & 0.172 & \multirow{2}{*}{-0.332} & 6.514 & .000 & .779 & 1.714 & \multirow{2}{*}{-.333} & \multirow{2}{*}{-.343} & \multirow{2}{*}{-.332} \\
\hline Dining out & -0.125 & 0.035 & & -3.598 & .001 & -.194 & -.056 & & & \\
\hline Family size & 0.191 & 0.069 & 0.256 & 2.780 & .007 & .055 & .327 & .257 & .272 & .256 \\
\hline
\end{tabular}

as the effect of lifestyle is concerned on the amount of wastes generated by households. It, however, fails to support the idea on the function of income and socio-economic factors on the matter.

This particular study does not find a positive correlation between income and wastes generated. It agrees with the Congress of the United States (1989) concerning the ambiguity in associating waste volume with income and social status on its generation. This is partly due to the difficulty in assessing the actual income of the residents. Other indications of disposable income such as number of cars owned and types of flooring used, should be used in future studies to imply income status of respondents.

The eating habits and family size of the residents of the study area, on the other hand, tend to influence the household weight significantly. It is therefore reasonable to conclude that future research should emphasize more on the role of householders' daily activities on the wastes than merely trying to link the waste volume to income levels.

The study also supports the idea presented by Tan (1986), referring to the main role played by the diversity of Malaysian community. He found that the consumption of large amount of food during the fasting month, festivals, fruit seasons, and night and wet market activities increased the solid waste generation. Conversely, the emergence of 'TV dinner', pre-cooked food, cold and frozen food, catered food, and habit to eat out (especially among Chinese) would tend to reduce the waste generation at household level.

Even though there are various factors influencing the generation of household waste, the most important one is appeared to be socially related. As far as its implication on future studies is concerned, more specific waste reduction issues such as the level of recycling activities of the community and use of kitchen grinder, for instance, should be looked into to provide more comprehensive data for a better policy formulation in the future.

It is believed that these lifestyle factors need to be studied either independently or in cohort to indicate their magnitude of influence on the variation and on trend of 
solid waste generation among Malaysians as a whole. A more detailed and comprehensive research with a larger sample size is needed to suggest a more conclusive result in the future.

\section{ACKNOWLEDGEMENTS}

The authors would like to thank all the parties involved in making this study possible, particularly the research assistants and En. Jamaluddin Jamil of the Southern Waste Waste Management Sdn. Bhd. for the information and data related to the management of household wastes in the study area.

\section{REFERENCES}

[1] Abd. Karim, A. T., and F. Othman. 1996. The Effect of Living Standard and Culture on Refuse Generation in the Johor Bahru Area. Proceedings International Conference on Environmental Protection and Control Technology, Kuala Lumpur. (3): 1071-1078.

[2] Congress of the United States, Office of Technology Assessment, 1989.

[3] Kaur, H. 1995. Program Kitar Semula di Majlis Perbandaran PetalingJaya. An Undergraduate Thesis. Faculty of Civil Engineering. Universiti Teknologi Malaysia, Skudai.

[4] Nakamura M. 1989. An Overview of JICA Study: SWM Needs and Prospects in Malaysia: Would Japanese Statistics Infer Malaysia Future. Workshop for the Development and Importance of SWM Master Plan for Local Authority. Pulau Pinang.

[5] Park, S. 1998. Attitudes toward Waste Management and Environmental Policies in Washtenaw County, Wisconsin. A PhD Thesis.

[6] The Department of Census. 2000. Population Census. Kuala Lumpur: The Department of Census; The Government of Malaysia.

[7] Sabarinah Marzuky. 1997. The Effect of Socio-economy on Municipal Solid Waste Generation: State of Johor. A Master Thesis. Universiti Teknologi Malaysia.

[8] Salim, M. R., F. Othman, and S. Marzuky. 1994. Problems and Challenges of Solid Waste Management: A Case Study in South Johor, Malaysia. Jurnal Fakulti Kejuruteraan. Universiti Teknologi Malaysia.

[9] Southern Waste Management. 1998. 'Laporan Pengurusan Sisa Pepejal dan Pembersihan Secara Interim’. Johor Bahru: SWM Interim Report.

[10] Tan, K. K. 1986. Trends in Solid Waste Generation and Potentials for Recycling. National Seminar on Management and Utilization of Solid Waste. September 30-October 1, 1986.

[11] Yamane, T. 1973. Statistics: An Introduction Analysis. New York: US Harper Row. 